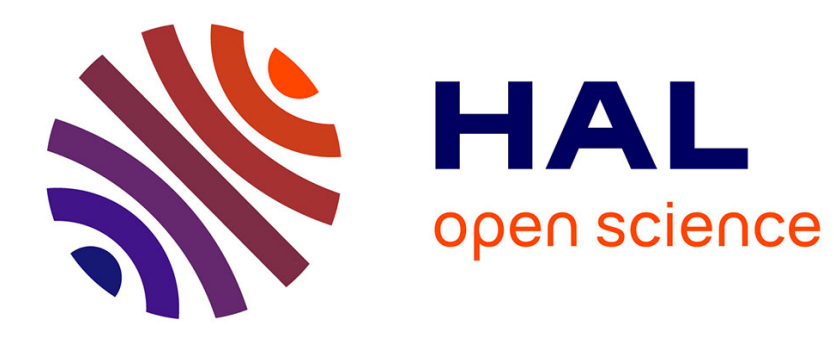

\title{
Bunyan and the Bedford Congregation
}

Anne Dunan-Page

\section{To cite this version:}

Anne Dunan-Page. Bunyan and the Bedford Congregation. Oxford University Press. The Oxford Handbook of John Bunyan, , pp.53-68, 2018, 9780199581306. halshs-01898899

\section{HAL Id: halshs-01898899 \\ https://shs.hal.science/halshs-01898899}

Submitted on 19 Oct 2018

HAL is a multi-disciplinary open access archive for the deposit and dissemination of scientific research documents, whether they are published or not. The documents may come from teaching and research institutions in France or abroad, or from public or private research centers.
L'archive ouverte pluridisciplinaire HAL, est destinée au dépôt et à la diffusion de documents scientifiques de niveau recherche, publiés ou non, émanant des établissements d'enseignement et de recherche français ou étrangers, des laboratoires publics ou privés. 


\title{
CHAPTER 3
}

\section{BUNYAN AND THE BEDFORD CONGREGATION}

\author{
ANNE DUNAN-PAGE \\ AIX MARSEILLE UNIV, LERMA, AIX-EN-PROVENCE, FRANCE
}

\section{The Gathered Church}

In the early 1650s, John Bunyan joined a 'Congregation of Christ'—or gathered Churchin Bedford. As that term may seem somewhat abstract, we can borrow a more immediately telling phrase used about a similar community at Bristol: a gathered Church was a Church with a chimney in it. ${ }^{1}$ This was worship in a context of hearth and home. The beginnings usually lay with small groups of parishioners, who met in a private house to pray, to review sermon notes, to read the Scriptures, to fast or eat together, and sometimes simply to edify one other by godly conference. As their spiritual life matured and deepened, they might decide to assemble in a more formal manner modeled upon the practice of the first Christians as recorded in the New Testament. It was hospitality and neighborliness that mattered. ${ }^{2}$ The members wanted a Church where all could meet in the same place and know each other well. Following Matthew 18: 20 ('For where two or three are gathered

\footnotetext{
${ }^{1}$ The Records of a Church of Christ in Bristol, 1640-1687, ed. Roger Hayden (Bristol: Bristol Record Society, 1974), 86.

${ }^{2}$ See Adam Sills, 'Mr. Bunyan's Neighborhood and the Geography of Dissent,' ELH, 70 (2003), 67-87.
} 
together in my name, there am I in the midst of them'), they considered that a very small number of people, usually between three and seven, could form a congregation. ${ }^{3} \mathrm{~A}$ gathered Church was therefore born indoors, without either priest or sacrament, but with a handful of people, with bread, drink, prayer and godly conversation. The Bedford Church owed its existence to such an idea of communion:

there hath of a long time bene persons godly, who in former times, (even while they remained without all forme and order as to visible church communion according to the Testament of Christ) were very zealous according to their light, not onely to edify themselves, but also to propagate the Gospell, and help it forward, both by purse and presence, keeping alwayes a door open and a table furnished and free. $(C B, 15)$

A gathered Church was 'a free society or communion of visible Saints, embodyed and knit together by a voluntary consent, to worship God, according to his Word, making up one ordinary congregation, with power of Government within it selfe only,' 'a company of Saints Assembling together in one place, built by a special covenant into one Distinct Body [...] to enjoy constant Fellowship with Christ in all his Ways and Ordinances. ${ }^{4}$ There would be much to comment upon in such expositions of Congregational polity. At the core of Congregationalist principles that inspired the gathering of a Church like Bedford lay the consent of 'visible' Saints who had entered into fellowship with God and each other, and the autonomy of congregations on questions of government and discipline.

\footnotetext{
${ }^{3}$ William Bartlet, Ichnographia. Or a Model of the Primitive Congregational Way (1647), 34; Thomas Goodwin, Of the Constitution, Right Order, and Government of the Churches of Christ (1696), Book VI, 241; John Williams, The Divine Institution, Order and Government of a Visible Church of Christ (1701), 4.

${ }^{4}$ Bartlet, Ichnographia, 30, Goodwin, Constitution, Book VI, 256.
} 
Bunyan probably never knew the Jacobean and Caroline conferences that nurtured the more formally organized Congregational Churches of the $1640 \mathrm{~s}$ and $1650 \mathrm{~s} .{ }^{5}$ What he did know, however, when he joined the Bedford Church, was the ecclesiastical settlement of the Cromwellian years, when a Congregational minister could hold a parochial living. Two of his predecessors, John Gifford and John Burton, had accepted the living of the parish Church of St John's, Bedford. ${ }^{6}$ These men were not 'separatists' or 'sectarians,' let alone 'Anabaptists,' but rather 'parochial' or 'non-separating' Congregationalists willing to operate within a national system. Even though they felt (as did Presbyterians) that the sacrament should be restricted to worthy believers, they considered parish Churches to be true Churches. Twenty years later, however, members of the Bedford congregation would be admonished for their 'evill in goeing to heare the nationall ministers' $(C B, 80)$, while others were sharply questioned about their 'seperation from the Church of England' $(C B$, 108). Interregnum parochial Congregationalism had given birth to separated Dissent.

The degree of commitment shown by Interregnum Congregational ministers to the parish has long been a matter of contention. ${ }^{7}$ Practical arrangements varied from place to

\footnotetext{
${ }^{5}$ See for instance, Patrick Collinson, ‘The English Conventicle,' in W. J. Sheils and Diana Wood (eds.), Voluntary Religion (Oxford: Basil Blackwell, 1986), 223-259; Alec Ryrie, 'Congregations, Conventicles, and the Nature of Early Scottish Protestantism,' Past \& Present, 91 (2006), 45-76.

${ }^{6}$ John Brown, John Bunyan: His Life, Times, and Work, rev. Frank Mott Harrison (London, Glasgow, and Birmingham: Hulbert, 1928), 66-90; Greaves, Glimpses, 61-7.

${ }^{7}$ Murray Tolmie, The Triumph of the Saints: The Separate Churches of London 1616-1649 (Cambridge: CUP, 1977), 85-119. For a recent reappraisal, see Joel Halcomb, 'A Social History of Congregational Religious Practice during the Puritan Revolution' (unpublished PhD thesis, University of Cambridge, 2010). For the pre-Revolutionary context, see Stephen Brachlow, The Communion of Saints: Radical Puritan and Separatist Ecclesiology, 1570-1625 (Oxford: OUP, 1988).
} 
place and cohabitation was not always peaceful. ${ }^{8}$ Members of a gathered congregation could hear their minister's sermon on Sunday, among the parishioners, and then hold separate meetings to deal with the internal affairs of their congregation, and to receive the sacraments. The ministers, at times, found themselves in an untenable position. Separatists accused them of meeting in impure buildings; Presbyterians charged them with being separatists, and parishioners claimed they looked after their own congregations and were therefore unfit recipients of their tithes. ${ }^{9}$

At the Restoration, the gathered Churches were forced to worship outdoors or to return to the enclosed spaces that had nurtured their tentative beginnings. In Bedford, this is recorded in late August $1660(C B, 36)$. Congregationalists had never truly left these domestic settings, for the Churches had met in the houses of their members throughout the $1640 \mathrm{~s}$ and the $1650 \mathrm{~s}$. The difference was that by the $1660 \mathrm{~s}$ these meetings became illegal 'conventicles:' a diminutive and disparaging form of the Latin conventus. The first Conventicle Act (1664) specified that the owners of a 'House, Outhouse, Barne, or Roome Yard or Backside Woods or Grounds' allowing meetings to be held on their premises would be punished. ${ }^{10}$ Bunyan, like many of his contemporaries, must therefore have joined worship in many different outdoor and indoor locations. His was a generation that might

\footnotetext{
${ }^{8}$ See Geoffrey Nuttall, Visible Saints: The Congregational Way 1640-1660 (Oxford: Basil Blackwell, 1957), 22-40, 134-37; Tolmie, Triumph of the Saints, 111-16; Susan Hardman Moore, Pilgrims: New World Settlers and the Call of Home (New Haven and London: Yale UP, 2007), 123-42; Ellen S. More, 'Congregationalism and the Social Order: John Goodwin's Gathered Church, 1640-1660', Journal of Ecclesiastical History, 38 (1987), 210-35; Francis J. Bremer, Congregational Communion: Clerical Friendship in the Anglo-American Puritan Community, 1610-1692 (Boston: Northeastern UP, 1994).

${ }^{9}$ More, 'Congregationalism and the Social Order,' 222-23; and on tithes, Nuttall, Visible Saints, $138-41$.

10 'Charles II, 1664: An Act to Prevent and Suppresse Seditious Conventicles,' in Statutes of the Realm: Volume 5, 1628-80, ed. John Raithby (1819), 516-520 (518).
} 
hear the Word of God as much in the chancel of a cathedral as in the front room of a godly widow. It is not surprising that the churches of his fictional and pastoral works are at once temples and cottages, palaces and inns. They were modelled on the meeting-houses of the Dissenting tradition, a term that survived the erection of legally tolerated chapels which were themselves inspired by domestic architecture.

In 1688, Bunyan published A Discourse of the Building, Nature, Excellency and Government of the House of God. His intentions here were practical; he wanted to provide a versified Church order. The 'house' is described as both a public and a private space, certainly not as a 'temple' only. It is a fortress, a palace, a stately home, but also an hospital, an inn, and an almshouse. 'Call this [...] what you will' is one of Bunyan's opening phrases $(M W, 6: 11.18-20,275)$. The nature of the building matters less than its materials: God's elect or 'living stones,' a metaphor used time and again in Congregational literature. ${ }^{11}$ Singled out among 'living stones,' were 'foundation stones,' the name given to founding members such as the twelve men and women of the Bedford congregation $(C B$, $17,63)$.

Such a shift of emphasis from material to spiritual stones might suggest an indifference to the physical construction and situation of the House of God. At the Restoration, after all, the multiplication of clandestine and ever-changing places of worship, together with a distrust of the legally established 'steeple-house,' meant that people, not spaces, were given pre-eminence. The Church existed where the Elect existed, even where no permanent, let alone dignified, buildings could be found. Although this was undoubtedly true, physical displacement also had the opposite effect. Historical circumstances had given Dissenters a heightened sense of place. The ideal Congregational

\footnotetext{
${ }^{11}$ Bartlet, Ichnographia, 31; John Owen, The True Nature of a Gospel Church and Its Government (1689), a2 ${ }^{\mathrm{r}}$; Benjamin Keach, The Glory of A True Church, And its Discipline Display'd (1697), 6.
} 
space represented by Palace Beautiful in The Pilgrim's Progress is primitive, modeled on the New Testament $(P P, 45-56)$. It is a domestic and homely place (more 'house' than 'palace,' despite its porter's lodge, chambers, study, and armory) whose inhabitants meet at nightfall to converse and eat supper. There, Christian could read not only the 'Acts' of his noble predecessors but also the 'Records of the House,' the minutes or book of that gathered Church $(P P, 53-54) .{ }^{12}$ The culture of the conventicles allowed the Dissenting congregations to revert to their original — indeed truly natural — mode of worship. The clergy, informers, and judges who pushed Dissent underground failed to remember that private worship behind closed doors was the original locus of Dissenting life and that it could become its strength again.

The Restoration also forced the Dissenters to reconsider their form of worship when no regular meetings could be held, when ministers were imprisoned, when letters replaced the spoken word, and baptisms were administered in the middle of the night. ${ }^{13}$ But even then, it did not entirely extinguish the experience of a Dissenting 'Church' after generations of Puritans had explained (parting company with Calvin on this point) 'the soteriological significance of ecclesiology. ${ }^{14}$ Church meetings were held, conversion narratives were heard, baptisms were performed, and sentences of excommunication pronounced, all in the midst of the harshest persecutions. In the following pages we will witness the paramount attention that was given to Church life by Bunyan and his fellowbelievers, following them from the Cromwellian era through the Restoration to the first decades of the eighteenth century: from St John's parish church to the barn that stood in

\footnotetext{
${ }^{12}$ See Robert Archer, 'Like Flowers in the Garden: John Bunyan and his Concept of the Church,' $B Q, 36$ (1996), 280-93.

${ }^{13}$ H. G. Tibbutt (ed.), Some Early Nonconformist Church Books (Bedford: Bedfordshire Historical Record Society, 1972), 28.

${ }^{14}$ Brachlow, Communion of Saints, 35 .
} 
the orchard of the brazier Josias Ruffhead, and to their first erected chapel in 1707. A convincing story could be assembled from Bunyan's works of fiction, but this one will be recounted from a document perhaps as extraordinary in Dissenting culture as The Pilgrim's Progress: the minutes of the Bedford congregation that were kept from 1656 to 1821.

\section{The Bedford ChurCh Minutes}

The tall folio that provides the evidence for this chapter, today in the John Bunyan Museum (Bunyan Meeting, Bedford), was published in facsimile in 1928, with an introduction by G. B. Harrison. It was transcribed and edited by H. G. Tibbutt in 1976, and a new edition is being prepared by Michael Davies. ${ }^{15}$ The records of meetings begin in 1656, though entries for the years 1656-71 have evidently been copied from an earlier and no longer extant source, with a retrospective narrative of the foundation of the Church in 1650 and an epistle from its first pastor, John Gifford, written just before his death in September 1655, also having been inscribed at the beginning. It is clear from this document that he saints who intended to gather a Church were never reluctant to seek help from other congregations and ministers, to correspond with each other, to send messengers to gather information, or to require the presence of neighboring elders. Guidance was at hand on most aspects of ecclesiology but one: the way the Church should keep and preserve its records. As a result, historians today are confronted with a wide variety of documents that pass under the name of 'Church books' or 'Church records.'

The Bedford manuscript, entitled 'A Booke Containing a Record of the Acts of A Congregation of Christ, in, and about Bedford,' is referred to internally as 'the church booke' $(C B, 34,85)$. 'Acts' was an important term, redolent of Apostolic times and

\footnotetext{
${ }^{15}$ See The Church Book of Bunyan Meeting, 1650-1821, intro. G. B. Harrison (London and Toronto: Dent, 1928); and $C B$.
} 
emphasizing the nature of a gathered Church as a voluntary association taking autonomous actions. In large metropolitan congregations, there is evidence that three, and sometimes four, separate documents could be kept at the same time: an account book, a minute book to record the decisions of the monthly assemblies, a Church book in which important events or controversies were transcribed, and a register of members. In smaller congregations, one book might fulfill all of these functions. The fact that the Bedford manuscript has no section dedicated to its finances suggests that a separate account book was in use, which has unfortunately not survived. The extant manuscript contains, for the most part, the minutes of the Church meetings and registers of members. In that sense, the term 'Church Book,' the abbreviated title given by Harrison, and the one by which the document has come to be known in Bunyan scholarship, is slightly misleading.

Until recently, scholars have been reluctant to broach these documents, being understandably suspicious of their incompleteness, their partiality, and the uneven geographical distribution of what happens to survive. ${ }^{16}$ The Bedford book is nevertheless a point of entry for studying Bunyan's career as the minister of a gathered Church and also indeed for the criticism of his writings, as Davies has so eloquently shown. ${ }^{17}$ It is very important to emphasize here that the autonomy of each congregation does not invalidate any remarks we might wish to make about the way each one fitted into a Congregational polity. The Bedford manuscript is often representative of other surviving Church records, even though its depth of detail and patient transcription of information over more than 200

\footnotetext{
${ }^{16}$ James F. Cooper, Tenacious of their Liberties: The Congregationalists in Colonial Massachusetts (New York and Oxford: OUP, 1999); Halcomb, 'Social History.'

${ }^{17}$ Michael Davies, 'Spirit in the Letters: John Bunyan's Congregational Epistles,' The Seventeenth Century, 24 (2009), 323-60.
} 
folios make it one of the fullest in existence. ${ }^{18}$ The reinscription into a new book of entries recorded between 1656 and 1671 occurs just a few months before Bunyan was elected. Perhaps it was Bunyan himself who insisted on this more systematic and organized recordkeeping, in the light of his Restoration efforts to maintain and encourage membership. ${ }^{19}$

\section{Visible SAINTS}

One of the most controversial aspects of Congregational ecclesiology was the admission and ejection of members. For Congregationalists, admittance to the Church was subordinated to a long process that included a spiritual examination of a prospective member by the whole Church and an enquiry into his or her 'conversation.' When a Church was formally gathered, the founding members, who had known each other for many years, did not always need further testimonies of their spiritual worth. In some cases, on the very day, they did relate their 'awakening' or 'conversion' again, but there is no trace of this in the Bedford minutes. The Bedford Church originally embodied through the willingness of its first brothers and sisters simply to enter into a covenant with God and each other:

\footnotetext{
${ }^{18}$ For recent scholarly work on Church records, see Mark Burden, Michael Davies, Anne Dunan-Page, and Joel Halcomb, An Inventory of Puritan and Dissenting Records, 1640-1714 (2016), accessible at: http://www.qmulreligionandliterature.co.uk/online-publications/dissenting-records. See also, Michael Davies, Anne Dunan-Page, and Joel Halcomb (eds.), 'Dissenting Hands,' special number of BS, 20 (2016); Anne Dunan-Page, L’Expérience puritaine. Vies et récits de dissidents (XVIIe-XVIIIe siècle) (Paris: Éditions du Cerf, 2017); and Michael Davies, Anne Dunan-Page, and Joel Halcomb (eds.), Church Life: Pastors, Congregations, and the Experience of Dissent in Seventeenth-Century England (forthcoming, OUP). ${ }^{19}$ On Bunyan's election, see Michael Davies, 'When Was Bunyan Elected Pastor? Fixing a Date in the Bedford Church Book,' BS, 18 (2014), 7-41.
} 
The manner of their putting themselves into the state of a Church of Christ was:- after much prayer and waiting upon God and consulting one with another, by the Word, they, upon the day appointed for this solemne worke, being met, after prayer and seeking God as before, with one consent they joyntly first gave themselves to the Lord, and one to another by the will of God. $(C B, 17)$

These original members of the Bedford church were guided by John Gifford, who was immediately chosen as their pastor, but also by 'other ministers' of the 'Congregationall way,' with whom Gifford had met, and by 'members of other societyes' $(C B, 17)$, although no messengers from other Churches seem to have been present, as was often the case at the gathering of a new Church.

As soon as the Church was gathered, the founding members and their pastor established the criteria to determine admission: 'faith in Christ and holines of life, without respect to this or that circumstance or opinion in outward and circumstantiall things' $(C B$, 17). This was both typical and innovative. It was typical, because the Bedford congregation required that prospective applicants should give a testimony of their 'faith in Christ' before the Church, while their conduct was duly scrutinized; it was innovative, because agreeing to display a spirit of tolerance on 'circumstanciall' matters — baptism being a case in point—was turned into a condition for joining the Church. 'Open communion' was not a mere idea or principle in Bedford, but a founding article of the Church, and one that determined its membership. It was still compulsory to abide by it in 1697: 'Twas then agreed on also that all persons for the future that are admitted to fellowship do explicitely declare their approbation of, and do give up themselves upon, the stated principle of the Church, viz:- - faith in Christ and holiness of life, though there be different apprehensions in circumstantialls or externalls' $(C B, 111)$. 
The founding members had neither a written covenant nor even a confession of faith, another fairly untypical move for a Congregational Church. The drafting of a confession was proposed only in the summer of 1672 , but it had to be postponed, Bunyan being still in prison:

\footnotetext{
It was also agreed that a brief confession of faith be drawne up by the elders and gifted brethren of the congregation, against the next meeting: that after the Churche's approbation thereof it may be propounded to all that shall hereafter give up themselves to the Lord and us by the will of God, and their unfeigned consent thereto required. $(C B, 73)$
}

It is unclear whether such a document was ever written, but the fact that it was being discussed soon after Bunyan had composed A Confession of my Faith, and A Reason of my Practice (1672) to vindicate open-communion can hardly be a coincidence.

The lack of both a written covenant and a confession of faith can perhaps be explained by the extraordinary status acquired by another document: John Gifford's deathbed epistle to the Church $(C B, 18-21)$. It summarized its spirit and gave advice on Church discipline and government. The letter also provided practical and spiritual guidance, rendering other documents unnecessary. It was still read at Church meetings some forty years after it was drafted, where a covenant would normally have served this function: 'The Church principle as 'tis in the account of the Churche's first gathering, and Dr. Gifford's epistle to the Church, was read and by the Church still approved, and agreed to be maint[ained] as what is agreeable to God's word' $(C B, 108)$.

Once criteria of admission had been agreed, how did the Bedford congregation choose its members? First, an applicant had to manifest a 'desire' to join the Church—a step deemed important enough to be mentioned in the minutes. Then, he or she was heard during private visits. If everybody was satisfied, the person was 'propounded' to the whole 
Church. For a whole month, church members had the opportunity to make enquiries into the life of the applicant and the slightest 'uneasiness' or 'unsatisfaction' or 'objection' could halt the procedure, until it was resolved. The interval between being 'propounded' and appearing before the Church could nevertheless be extended. In 1697, a sister was admitted 'who for years past stood propounded but could not attend a Church meeting to be received' $(C B, 111)$. It took two years for Ann Muns, who had 'two bastards,' to show repentance and be finally accepted, 'giving in a very satisfactory experience' $(C B, 137)$. Conversely, there were cases in which members were propounded and received at the same meeting, or not propounded at all, but this measure remained exceptional. In November 1694, Alice Clarck 'was propounded and received into our fellowship both at the same meeting, not as a president for others, but because she feared she might be hindred her duty if her husband heard it' $(C B, 101)$. Later, there were cases of pregnant women who were exempt from having to deliver their 'experiences' before the church, as they were so close to giving birth $(C B, 124,127,132)$. On 26 June 1695, 'Josua Read of Cloph[ill] was received, though not before propounded, it being the request of his mother then present and he very well known to the Church; but this is not to be afterwards a praesident for other person' $(C B, 105)$. The minutes failed to record the precise nature of such motherly concern.

If nothing unfavorable was reported once the candidate had been propounded, he or she came before the Church to deliver a conversion narrative, or 'an acc[ount of] the work of grace' $(C B, 22)$, or an 'experience' $(C B, 25)$. Exemptions were sought - but not oftenand apparently always by women. Mrs Whitebread, for instance, was exempted 'because of the great distress she lay under at her speaking to the Church' $(C B, 129)$. A Mrs Freeman pleaded physical infirmities: 'Twas then also concluded that Mrs Freeman who stands propounded for communion, have libertie to speake her experience to some brethren 
in private, she not being able to speak before the Church by reason of her fitts, but not as a president for future practices' $(C B, 114)$. Other candidates failed to convince the assembly and were told to wait $(C B, 22)$. The Church ensured that they were properly looked after in the interval, 'to incourage them to farther waitinge, and indeavour the prevention of any temptation' $(C B, 24)$, but deferral could lead to complaints and grudges, as in the case of Hester Brace whose mother was exhorted 'not to conceive prejudice against any on her daughter's being refused for the present' $(C B, 146)$. There is no real indication that the Church lowered its standards of admission under persecution; people were still asked to wait when they were not considered to be ready $(C B, 40)$. If the relation were deemed satisfactory, the candidate was finally received into fellowship after a collective decision.

In Bedford, the visits that members paid to prospective applicants were often gendered: women visited women and men visited men. This was not a standard procedure among gathered Churches. When the minutes open, in April 1656, visits are mentioned but the 'propounding' stage seems to have been omitted; brothers and sisters apparently had the power to invite an applicant to the next Church meeting to deliver his or her experience, after one, two, or three visits. Not all Churches would have admitted such private screening by lay members, and this seems to have ended abruptly in the latter part of 1657 . From then on, the records mention that members were 'propounded' before being allowed before the Church. For the first two years of the minutes, 1656 and 1657, the pastor John Burton is mentioned only once in relation to the visits. It seems curious that a pastor would almost systematically delegate this important work to ordinary members and refrain entirely from participating in the admission process. It should not be forgotten, however, that Gifford's epistle had recommended that a pastor should be on trial for one or two years before his election $(C B, 21)$. Perhaps Burton was on trial only, until late 1657 (although he was appointed to the St John's living in January 1656). A meeting in August 
of the same year nominated other 'officers necessary for the congregation.' Bunyan was one of them, though he would be exempted from serving as a deacon at this time on account of his preaching activities $(C B, 28)$.

A second point concerns the audience for the conversion narratives that applicants were required to give. Polemical tracts from the 1640 s reveal that narratives were originally given in New England on Sundays, when not only members of the Church, but also children and outsiders to the community, were present. ${ }^{20}$ Listeners could then learn how to frame a suitable account by listening to those of others. In Bedford, a narrative could indeed be heard on the Lord's Day, at least after the Restoration $(C B, 111,120,123)$, but it was not the Church's regular practice. Most members were heard during the monthly Church meetings which, in theory, were accessible only to Church members. There is, however, a late entry that points out into another direction. On 26 February 1707, five newcomers were admitted but 'Samuell Hensman, before propounded, his speaking his experience was defered till next meeting because many members were dissatisfyed with him, and there was such an appearance of strangers at this Church meeting that 'twas not thought convenient to enter upon the debate about him' $(C B, 133)$. This crucial entry provides evidence for the way the congregation had evolved in the early eighteenth century. First of all, meetings dealing with the internal affairs of the Church in general, and cases of discipline in particular, had been opened to non-members, at an unspecified date, but before 1707, when the Church was worshipping and holding its meetings in a brandnew chapel. Second, the Church was becoming increasingly sensitive to issues of privacy. It would take another decade to resolve the matter. On 3 September, 1718, 'it was resolved not to admit any person to our Church meetings, for Church business, but Church members, or transient members, or those propounded' $(C B, 146)$. Bedford was closing its

\footnotetext{
${ }^{20}$ See, for instance, Thomas Lechford, Plain Dealing: Or, Newes from New-England (1642).
} 
door to 'strangers' with the effect that its eighteenth-century applicants for membership cannot have had access to first-hand testimonies of experiences. If Bedford was typical of a general move towards increased privacy, then the evangelical conversion narratives of the eighteenth century could hardly have been studied, so to speak, within the walls of the meeting-houses. $^{21}$

The admission procedures described so far were followed for anyone not already a member of a gathered Church. If an existing member ofanother congregation wished to join, however, a dismission was required from that congregation, usually in the form of a testimonial letter. Most Churches considered that this was a sufficient qualification for membership. Bedford, however, insisted that even these people should deliver a conversion narrative when they arrived. Conversely, some members of the Bedford Church asked for a recommendation when they changed residence. The Churches to which they were entrusted give an idea of the Bedford network: in London, the congregations of Henry Jessey, George Cockayne, John Owen, Anthony Palmer, George Griffith, John Simpson, Richard Taylor, Matthew Meade, John Nesbitt, and Robert Trail. Some of these were directly consulted at various times, for instance to find an assistant to the ailing Burton $(C B, 34,66)$ or a replacement for Bunyan $(C B, 91)$.

In nearby areas, Bedford was in contact with the Church of Stephen Hawthorne at Stevington and had entered into association with those of John Donne (the ejected rector of Pertenhall) at Keysoe, William Wheeler at Cranfield, and John Gibbs at Newport Pagnell $(C B, 31,35)$. These Churches were to be consulted in case of difficulties, to assist in preaching, to help administer the sacrament, or to give advice on the choice of a pastor, and could be asked to spare a gifted brother to assist, for example, with preaching. As in all

\footnotetext{
${ }^{21}$ For the opposite hypothesis, see Bruce D. Hindmarsh, The Evangelical Conversion Narrative: Spiritual Autobiography in Early Modern England (Oxford: OUP, 2005), 293.
} 
such associations, messengers met, discussed Church affairs, and couched their proceedings in writing: an entry for March 1659 refers to 'the 8th proposall of our agreement with other congregations adjacent' $(C B, 33) .{ }^{22}$ Bedford was also at the centre of a cluster of satellite 'meetings' in villages and hamlets from which it drew members, all 'upheld by the congregation' $(C B, 86)$. In 1672 , licences were sought for no less than eleven such locations in Bedfordshire, Hertfordshire and Cambridgeshire. ${ }^{23}$ Some, such as those at Gamlingay and Blunham, would eventually 'inchurch by themselves,' with Bedford's approval, respectively in 1710 and $1734(C B, 134-35,155)$.

All the above London and Bedfordshire Churches were Congregational. There is no indication that the Church was willing to dismiss members to Baptist Churches who did not practice open communion or even to Churches 'whose principles and practices, in matters of faith and worshippe, we as yet are strangers to' $(C B, 66)$. For instance, in May 1674 a letter was dispached to the congregation of the late Henry Jessey to ensure that it was still practising open communion and could therefore receive one member of the Bedford Church, now a London resident, named Martha Cumberland $(C B, 77,79)$. Martha had been given a choice between the congregations of George Cockayne, Anthony Palmer, and John Owen, but had declined. Bedford feared she might have adopted closedcommunion views. The letter, signed by Bunyan, was respectful of John Gifford's tolerance over baptism, and yet it effectively forbade a member to join with the congregation of her choice. As I have suggested elsewhere, if Bunyan was labelled an

\footnotetext{
${ }^{22}$ See B. R. White, 'The Fellowship of Believers: Bunyan and Puritanism,' in N. H. Keeble (ed.), John Bunyan: Conventicle and Parnassus (Oxford: Clarendon Press, 1988), 1-19.

${ }^{23}$ Blunham, Goldington, Oakley, Kempston, Cardington, Stagsden, Haynes, Maulden, Edworth, Gamlingay, Toft, and Ashwell. See Brown, John Bunyan, 210-38; Richard L. Greaves, 'The Organizational Response of Nonconformity to Repression and Indulgence: The Case of Bedfordshire,' Church History, 44 (1975), 47284; Geoffrey F. Nuttall, 'Church Life in Bunyan's Bedfordshire,' BQ, 26 (1976), 305-13.
} 
'Anabaptist' it had more to do with polemics than with Church practice. ${ }^{24}$ Not only was he not a strict Baptist himself (and had his children baptized as infants) but he was clearly reluctant to recommend members to closed-communion Baptist Churches.

\section{BEDFORD'S OFFICERS}

The 'embodying' of a Church preceded the election of its officers. Most Churches were originally gathered without a minister; if necessary, they could function without one for weeks, months, or even years. This was indeed mentioned in John Gifford's epistle: the Church ought to continue as a Church, if their 'teacher at any time be laide aside' $(C B, 21)$. It is not always easy, though, to determine the role of officers in Bedford, due to the Church's idiosyncratic use of its terms and their variation over time. Congregational polity distinguished between the offices of 'pastor,' 'teacher,' 'elders,' and 'deacons,' but without attributing pre-eminence to either pastor or teacher. ${ }^{25}$ In Bedford, John Gifford had used 'overseer,' 'teacher,' and 'pastor' indiscrimately $(C B, 18,21)$, and John Burton was referred to as a 'teacher' $(C B, 38)$, although he clearly fulfilled the functions of a 'pastor' as well. In January 1659, as his health declined, the congregation appointed two 'elders,' John Whiteman and John Grew $(C B, 32)$ and it was suggested that an 'assistant' should be found with the help of London ministers $(C B, 34)$. Samuell Fenne and John Whiteman were referred to as 'overseers,' 'pastors,' 'elders,' 'ministers,' and even 'bishops,' the

\footnotetext{
${ }^{24}$ Anne Dunan-Page, Grace Overwhelming: John Bunyan, The Pilgrim's Progress and the Extremes of the Baptist Mind (Bern: Peter Lang, 2006), 47-100.

${ }^{25}$ The Savoy Declaration, in The Creeds and Platforms of Congregationalism, ed. Williston Walker, intro. Elizabeth C. Nordbeck (1893; rpr. New York: Pilgrim Press, 1991), 340-408 (404); James M. Renihan, Edification and Beauty: The Practical Ecclesiology of the English Particular Baptists, 1675-1705 (Milton Keynes: Paternoster, 2008), 88-117; Halcomb, 'Social History,' 63; Bartlet, Ichnographia 62-4; Goodwin, Constitution, Book VI, 279-90.
} 
latter term being normally favored by Baptists $(C B, 50)$. Bunyan was elected 'to the pastorall office or eldership' $(C B, 71)$. Similarly, the first mention of Bunyan's successor, Ebenezer Chandler, is both as 'pastor and elder' $(C B, 90)$.

Election preceded the ordination of officers, which normally comprised fasting, praying, and the laying on of hands of the eldership. Yet this is not a point on which the Bedford minutes give much information. The founding members, we are told, simply 'made choyce' of Gifford without neighboring elders being present, while Burton's election is not even mentioned, and Samuel Fenne and John Whiteman's appointments are simply alluded to $(C B, 17,38-9)$. Likewise, Bunyan is described as having been given 'the right hand of fellowship' (Galatians 2: 9), whereas Chandler was 'elected and sett apart to the work and office of pastor' $(C B, 94)$. In practice, moreover, the management of the Bedford congregation was mostly in the hands of a single person named overseer, bishop, teacher, pastor, elder or pastor and elder — when there was one. The only exception was between 1663 and 1681. In December 1663, the haberdasher Samuel Fenne and the yeoman John Whiteman were joyntly elected as 'pastors and elders' $(C B, 38)$. In May 1674, in connection with Martha Cumberland's affair (noted above), Bedford received a letter from the congregation of the late Henry Jessey, addressed 'To the church of Christ in Bedford wherof our beloved Samuell Fenn is pastor' $(C B, 79)$, Whiteman having died in 1672. Either the news of Bunyan's election in December 1671 must have taken considerable time to reach the capital or the congregation deliberately omitted his name. ${ }^{26}$ The latter is a distinct possibility. After all, Bunyan had recently appended Jessey's principles to his Differences in Judgment About Water-Baptism, No Bar to Communion (1673) — and yet now questioned this London Church's faithfulness to their former minister's spiritual legacy.

\footnotetext{
${ }^{26}$ On the date of the election, see Davies, 'When Was Bunyan Elected Pastor?'
} 
It may well be that Bunyan's appointment to the Bedford pastorate was not as straightforward as it seems with hindsight. It is true that William Whitbread, in a letter to the congregation, had mentioned his dissatisfaction with the dual leadership of Fenne and Whiteman $(C B, 47)$ and Michael Davies has shown that the correspondence inserted in the Church Book might have served as a campaign to promote Bunyan's qualifications to the pastorate. ${ }^{27}$ And yet, such isolated complaints (Whitbread repented in October 1671) would not have been sufficient to challenge the co-pastors' leadership, especially since it was in perfect agreement with Congregational polity. The appointment of Bunyan was a somewhat strenuous affair. It took no less than five meetings, in three different places, to prepare it, and much 'conference' and 'prayer' so 'that [the Church's] way in that respect may be cleared up to them' $(C B, 70)$. We do not know how Fenne and Whiteman took it or, more importantly, how their roles were altered after the new appointment. In May 1672, they both applied for licences to teach in satellite meetings, at Cardington and Haynes, respectively. Somewhat conveniently, Whiteman died soon afterwards, but that leaves open the possibility that Bedford had three 'pastors or elders,' at least for a few months. Fenne lived until November 1681 being described at his death as 'one of the elders of this congregation' $(C B, 86)$. Just before, he and Bunyan had signed a letter of admonition to Sister Hawthorne as 'elders' $(C B, 85) .{ }^{28}$ Whatever happened in the Bedford congregation in the winter and spring of 1671-72, Whiteman and Fenne must have consented to enter into an unusual pastoral triumvirate, granting pre-eminence to Bunyan as soon as he was released from prison.

Samuel Fenne died on 12 November 1681. The Church used a similar phrase, citing God's 'heavie hand,' as it would for Bunyan seven years later $(C B, 86,89)$, and appointed

\footnotetext{
${ }^{27}$ Davies, 'Spirit in the Letters,' 340.

${ }^{28}$ Greaves, 'Organizational Response,' 478.
} 
in both cases the holding of a day of humiliation. Fenne's death led directly to a reorganisation of the internal affairs of the Church, among which the institution of the office of 'ruleing elders,' whose 'qualifications' were considered 'in order to choyce and apointment of som to that work in this congregation' $(C B, 87)$. It seems that Bunyan was unwilling to repeat the experience of a decade of shared pastoral leadership: he became the sole overseer of the congregation while ruling elders assisted in matter concerning discipline. This is what he would later theorize in A Discourse of [...] the House of God, where he distinguished between 'overseers,' 'rulers,' 'deacons,' and 'widows.' The overseer, a 'Distributor of the word of Grace' $(M W, 6: 1.397,286)$, was meant to exhort, preach sound doctrine, administer the sacraments, and exercise a cure of souls. The ruling elders were to enforce appropriate discipline and keep schisms and contentions at bay $(M W, 6: 11.514-31,289-90)$. Deacons were in charge of charitable works, while widows were supposed to instruct 'Younger Women' and visit the sick (MW, 6: 11. 580, 586, 291). Although Bunyan explicitly recognized the role of widows in print, the Bedford congregation does not seem to have had 'widows,' but it did have elected deacons in charge of the finances. There were at least three of them during Bunyan's pastorate. 'Gifted' brothers whose 'call' to preach had been endorsed by the Church were also vital to maintain the circuits of satellite meetings in the area, and, at the same 1681 meeting, it was decided they should all meet, once every six weeks. More complex was the identity and role of the 'principall' brethren (sometimes also named elders) because — unlike pastors, ruling elders and deacons - these were not formally elected by the Church. Such brethren are mentioned for the first time in July 1658 , when it was decided that they would meet to prepare the Church's meetings and set the affairs in 'order and readiness' $(C B, 30)$. In London, though not explicitly in Bedford, there were concerns that they instituted an oligarchy of eminent members who would use their private meetings to steer the general 
assembly, in direct opposition to the Congregational principle of open discussion of the Church's affairs (at least among male members). ${ }^{29}$ It is clear that they continued to operate in the Bedford Church during the Restoration, but whether they were ever elected officially as ruling elders remains uncertain $(C B, 50,67,70)$.

\section{AbSentees ANd LeWd Livers}

Discipline within the Bedford Church was always a key concern, and the minutes dedicate a great deal of attention to the activities of the congregation's disorderly walkers, as such church records often describe them. Scandalous livers, however, could easily be identified and, in that sense, caused fewer problems than did brothers or sisters who had become disaffected with the Church and stopped attending the Lord's Supper and meetings. Even if attendance at the latter was not compulsory, it was expected that members would show an acceptable degree of commitment. 'Generall' meetings were also held (in the 1650s, quarterly; after the Restoration, yearly) at which everybody was supposed to come 'without any delay or excuse' $(C B, 35)$. These meetings were specifically designated to 'inspect the state of the Church' $(C B, 136)$, and yet some members still failed to turn up. It therefore became necessary to remind everybody, at regular intervals, that an interest in the collective management of the Church affairs, as well as participation to the sacraments and 'performing with other spiritual services as tend to their mutual edification,' was not optional. ${ }^{30}$ In October 1656, it was decided that two brethren would visit the members 'to certify us how they doe in body and soule, and to stirre them up to come' $(C B, 23)$. Two years later, in order to facilitate the work of its visitors, the Congregation was divided into

\footnotetext{
${ }^{29}$ Renihan, Edification, 81; Murdina D. MacDonald, 'London Calvinistic Baptists 1689-1729: Tensions within a Community Under Toleration' (unpublished DPhil thesis, University of Oxford, 1982), 109-31. ${ }^{30}$ Savoy Declaration, 397.
} 
several districts: brothers were appointed for Bedford, Kempston, Houghton Conquest, Wilshamstead, Elstow, Cardington, Oakley, Stevington, and Radwell, to which were later added 'Fensom' and Haynes $(C B, 30,38)$. After 1688, they were visiting 'Bedford and adjacent places,' 'Cotten End, and thereabouts,' 'Bletsoe and round him [sic],' and 'Gamlingay and those parts' $(C B, 104)$.

Those visits maintained a vital link between members who lived far apart, to give comfort to the sick and to those 'complaining of lowness in their spiritts' $(C B, 128)$, such as Sister Chamberlaine who was visited 'in a very sad condition by reason of temptation' $(C B, 33)$. They were also used to keep a tally of membership. One of the first measures taken by Ebenezer Chandler, elected pastor in 1691, was 'an inspection how those members stand that are under the senshures of the Church, or have at any time been admonished, and to know what there offences are and who do absent from the Church meeting' $(C B, 95$ and also 101). Because of the gathered Churches' insistence on godly fellowship and strict watchfulness, it has often been supposed that membership must have been kept under strict control. In fact, loosened spiritual bonds, unrecorded changes of residence, and series of unanswered admonitions all meant that the officers rarely had a clear idea of the precise size of their flock, hence the need for visitations. In 1694, it was recommended that a visit should finally be paid to Oliver Dix who had been 'withdrawn' from the Church, without ever leaving it, for the last thirty-three years $(C B, 100)$. How exactly Dix thought about his relation to the Church can only be a matter of conjecture. Like some others before and after him, he may have quietly slipped back to parish worship, avoiding his former companions, without reflecting unduly upon his role as a member of a dissenting brotherhood.

Such cases of absenteeism are carefully recorded in the Bedford volume alongside more colorful or tragic forms of misdemeanor: playing at cards (or shuffle-boards, quoits, 
or nine pins), drunkenness, adultery, 'carnal' marriages, ancillary elopement, 'light unbecoming actions about stool ball and the may pole' $(C B, 124)$, attempted suicide, wifebeating, getting into debt, sabbath-breaking, and prophesying. Recorded cases of such crimes swelled at the Restoration and beyond, but it is impossible to determine whether the Church had become stricter and more systematic in its exercise of discipline or whether the minutes began to be kept, on that particular point, with greater care and regularity.

Doctrinal or ecclesiological errors were also a source of anxiety, such as insisting on adult baptism, refusing to sing hymns, asserting that 'the soul was perfect' $(C B, 159)$, 'going to the Moravians' $(C B, 175)$, or simply hearing 'nationall' ministers $(C B, 40,51,56,63$, 115).

In cases of 'passive' absenteeism or 'active' wrongdoing, the procedure was identical. The person was admonished, once or twice, in private, and then asked to come and explain himself or herself before the whole Church. Some excommunications were nevertheless judged too sudden $(C B, 148)$. In one instance, it was considered that two brothers might be excommunicated 'forthwith' for drunkenness, but the 'more ordinary way' was to give a warning $(C B, 116)$. Members were naturally sensitive to due procedure. A 'private' offence would normally be dealt with first in private, a 'public' offence before the whole Church. Some, then, took upon themselves to remind the Church of the nature of a 'public' offence. In 1694, John Hensman interrupted the proceedings of the assembly on the grounds that his disciplinary appeareance before the Church, on account of running into debt, was disorderly, 'alledging that noe faults deserve publick dealing but gross enormityes and haresyes' $(C B, 99,101)$. If little or no repentance was shown, the person would be 'withdrawn from,' meaning that he or she could still come to hear sermons and participate in public events but was barred from the communion table. After a period of time which could vary considerably from case to case, a sentence of excommunication was 
officially pronounced, entered in the minutes, and notified, in person, to those concerned. It should be noted that the Church's censures did not spare its main officers. In August, 1669, Edward Coventon (the husband of one of the founding members) and William Wallis were removed fromthe church's diaconate on account of their negligence.

It has sometimes been supposed, given the apparent rigidity of moral standards and the obligation of members to keep watch upon each other that gathered Churches were as quick to sever themselves from backsliders as they were slow in admitting visible Saints. Nothing could be further from the truth. The community was aware that excommunication was a last resort, delivered only when everything else had failed, and then only after protracted debate. It was also reversible. Cases were examined with scrupulosity, witnesses were heard, the offender was given every opportunity to repent, and the Church prayed and fasted regularly for the return of the prodigal $(C B, 39)$. The nature of the offence, and its supposed gravity, mattered far less than a willingness to confess and acknowledge one's sins before God, the Church, and oneself $(C B, 149)$.

Marrying outside the faith was a case in point. In theory, this was strictly forbidden, but when the deed was done, no remedy could be found, unless the Church was willing to excommunicate the offender. This rarely happened and expedients were found. An ungodly wife or husband could prove to be 'gracious' $(C B, 120)$; a misguided wife might confess she had acted rashly. Acknowledgment of wrong-doing and repentance might be sufficient to assuage the ire of the pastor $(C B, 115-16,128)$, especially if the newly-wed was happy to resume his or her place within the community $(C B, 176)$. Mary Gates, after months of admonition, came to plead her cause after she had been repeatedly seen in the parish Church with her 'carnall' husband: 'and for her going to Church 'twas to please her husband only, and that because he threatened otherwise to leave her and her children' $(C B$, 128). 


\section{CONCLUSION}

A full history of the Bedford congregation in the seventeenth and eighteenth centuries is still to be written. In the space available here, it has been impossible to dwell on topics that would require an entirely separate treatment, such as the role of the Bedford sisters or hymn singing. Neither has it been possible to provide a systematic comparison with other Congregational Churches. It has been possible, however, to reconstruct the breadth of John Bunyan's activities. His days were filled with visiting the sick and the spiritually afflicted, with stirring up the lukewarm, admonishing youngsters who had fallen in love around the maypole, notifying the excommunicated, listening to conversion narratives, investigating those churches elsewhere that might welcome his own members, drafting recommendation letters, or organising meetings. Such documents as the Bedford minutes deserve a more comprehensive treatment than they have hitherto received. The relationships between ordinary members and the elders, the shifting notion of a communal 'identity' within the Bedford Church of visible Saints who were also parents, husbands, wives, tradesmen and villagers, the tension between the autonomous congregations, the pre- and post-Toleration changes in Congregational ecclesiology — these are all topics which a study of John Bunyan's congregation and its records may help to illuminate.

\section{SUGGESTED READING}

Burden, Mark, Michael Davies, Anne Dunan-Page, and Joel Halcomb, An Inventory of Puritan and Dissenting Records, 1640-1714 (2016), accessible at: http://www.qmulreligionandliterature.co.uk/online-publications/dissenting-records.

Brachlow, Stephen, The Communion of Saints: Radical Puritan and Separatist Ecclesiology, 15701625 (Oxford: OUP, 1988). 
Cooper, James F., Tenacious of their Liberties: The Congregationalists in Colonial Massachusetts (New York and Oxford: OUP, 1999).

Davies, Michael, 'When Was Bunyan Elected Pastor? Fixing a Date in the Bedford Church Book,' $B S, 18$ (2014), 7-41.

Davies, Michael, Anne Dunan-Page, and Joel Halcomb (eds.), 'Dissenting Hands,' special number of $B S, 20$ (2016).

Greaves, Richard L., 'The Organizational Response of Nonconformity to Repression and Indulgence: The Case of Bedfordshire,' Church History, 44 (1975), 472-84.

Halcomb, Joel, ‘A Social History of Congregational Religious Practice during the Puritan Revolution' (unpublished PhD thesis, University of Cambridge, 2010).

MacDonald, Murdina D., 'London Calvinistic Baptists 1689-1729: Tensions within a Community Under Toleration' (unpublished D.Phil thesis, University of Oxford, 1982).

More, Ellen S., 'Congregationalism and the Social Order: John Goodwin's Gathered Church, 1640-1660,' Journal of Ecclesiastical History, 38 (1987), 210-35.

Nuttall, Geoffrey F., Visible Saints: The Congregational Way 1640-1660 (Oxford: Basil Blackwell, 1975). 